\title{
Jurist-Diction
}

Volume 2 No. 5 September 2019

Histori artikel: Submit 12 Juli 2019; Diterima 10 Agustus 2019; Diterbitkan online 1 September 2019.

\section{Eksekusi Pidana Mati Pidana Mati Terhadap Narapidana yang Mengalami Sakit Kronis}

\author{
Rizka Fatrian Larasanti \\ rizkafatrianlarasanti@gmail.com \\ Universitas Airlangga
}

\begin{abstract}
The execution of death penalty shall be conducted based on the specified schedule. It is not allowed for the convicted criminal being in the long term procrastination. This condition can lead to the death row phenomenon for the convicted criminal which can affect to the physical health of the convicted criminal. The rights of convicted criminal which already covered by the constitution and other related regulation, such as right to be health, shall be fulfilled by the state. In case of the convicted criminal, according to the doctor, has chronic illness, there is a provision which stipulate about the procrastination of the execution of death penalty. This provision is regulated under article 7 Law Number 2/Pnps/1964 on The Procedures of The Execution of Death Penalty sentenced by General Court and Military Court. The purpose of this thesis is to analyze the execution of death penalty for the convicted criminal with chronic illness. This thesis is a juridical-normative thesis which use statute and conceptual approach.
\end{abstract}

Keywords: Penalization; Death Penalty; Execution of Death Penalty, Procrastination of the Execution of Death Penalty; Chronic Illness.

\begin{abstract}
Abstrak
Eksekusi pidana mati seharusnya dilakukan sesuai dengan waktu yang telah ditentukan, dan tidak diperkenankan terhadap seorang narapidana yang berada dalam kondisi penundaan yang cukup lama. Hal ini dapat menyebabkan seorang narapidana mengalami bentuk penyiksaan psikologis (death row phenomenon) yang dapat berpengaruh pula pada kesehatan fisik narapidana hingga narapidana dapat mengalami sakit selama didalam LAPAS. Hak-hak narapidana seharunya juga harus dipenuhi oleh negara, seperti hak kesehatannya yang melekat dan telah dijamin oleh negara melalui Undang-Undang Dasar Negara Republik Indonesia 1945 dan peraturan perundang-undangan lainnya. Menghadapi situasi narapidana yang mengalami sakit hingga divonis oleh Dokter mengalami sakit kronis, Pasal 7 Undang-Undang Nomor 2/Pnps/1964 tentang Tata Cara Pelaksanaan Pidana Mati yang Dijatuhkan Oleh Pengadilan Di Lingkungan Peradilan Umum dan Militer mengatur tentang penundaan eksekusi mati. Tipe penelitian ini adalah penelitian hukum normatif dengan menggunakan metode pendekatan perundang-undangan, pendekatan konseptual. Tujuan dari penelitian ini memiliki kajian terhadap pelaksanaan eksekusi pidana mati jika terpidana mengalami sakit kronis.
\end{abstract}

Kata Kunci: Pemidanaan; Pidana Mati; Eksekusi Mati; Penundaan Eksekusi Mati; Sakit Kronis.

\section{Pendahuluan}

Hukuman mati masih menjadi polemik di dunia peradilan di Indonesia. Isu ini tidak hanya berhenti di lingkup Nasional tetapi juga Internasional. ${ }^{1} \mathrm{Hal}$

1 Muthia Novany, Ekseskusi Mati Terhadap Terpidana Mati yang Mengalami Gangguan Jiwa, Skripsi, (Program Sarjana Universitas Airlangga 2017).[1]. 
tersebut dikarenakan karena pidana mati merupakan hukuman yang paling berat dan dianggap bertentangan dengan Hak Asasi Manusia. Indonesia menjadi salah satu negara yang disorot dunia karena kebijakannya mengenai eksekusi mati terpidana kasus narkotika. Beberapa organisasi Hak Asasi Manusia Amnesty International mengkritik agar Indonesia menerapkan moratorium hukuman mati, serta jalur diplomasi dengan pemerintah untuk menyelamatkan WNA yang akan dieksekusi mati.

Motif atau tujuan hukuman mati dalam berbagai peraturan yang ada menunjukkan pola yang konsisten. Beberapa motif yang paling popular di Indonesia yakni dapat menimbulkan shock therapy disamping itu juga lebih hemat $^{2}$ dan hukuman mati digunakan agar tidak eigenrichting dalam masyarakat. ${ }^{3}$ Indonesia sebagai negara hukum yang tertutang dalam pasal 1 angka 3 UUD NRI $1945^{4}$ memberi penegasan bahwa apapun yang dilakukan oleh masyarakat maupun pemerintah harus berlandaskan hukum dengan memperhatikan norma yang ada.

Pada hakekatnya hukum pidana merupakan suatu perlindungan terhadap masyarakat dan perbuatan melanggar hukum yaitu bahwa pidana diharapkan sebagai sesuatu yang akan membawa kerukunan dan pidana adalah suatu proses pendidikan untuk menjadikan orang orang dapat diterima kembali dalam masyarakat maka tujuan dari hukum pidana adalah untuk memenuhi rasa keadilan. ${ }^{5}$ Peraturan hukum lebih banyak mengarah pada kepastian hukum, sehingga keadilan sulit untuk dicapai, namun dalam keadaan konkrit, keadilan dan kepastian hukum saling mendesak maka dalam melakukan penafsiran hukum atau hakim dalam menjatuhkan putusan harus mengutamakan keadilan diatas kepastian hukum.

Yang menarik perhatian dari hasil putusan Mahkamah Konstitusi No 2-3/ PUU-V/2007 adalah dalam putusan tersebut terlepas dari pendapat Mahkamah perihal tidak bertentangnya pidana mati dengan UUD NRI 1945 bagi kejahatan-

\footnotetext{
Akhiar Salmi, Eksistensi Hukuman Mati (Aksara persada 1985).[127].

ibid.

Undang-Undang Dasar Negara Republik Indonesia 1945, Ps.1 angka 3.

5 Wirjono Prodjodikoro, Asas-Asas Hukum Pidana Di Indonesia (Eresco1989).[21].
} 
kejahatan tertentu dalam UU Narkotika yang dimohonkan pengujian dalam permohonan a quo, dengan memperhatikan sifat irrevocable pidana mati, terlepas dari pendapat Mahkamah perihal tidak bertentangnya pidana mati dengan UUD 1945 bagi kejahatan tertentu dalam UU Narkotika, Mahkamah berpendapat bahwa ke depan dalam rangka pembaruan hukum pidana nasional dan harmonisasi peraturan perundang-undangan yang terkait dengan pidana mati, maka perumusan, penerapan, maupun pelaksanaan pidana mati dalam sistem peradilan pidana di Indonesia hendaklah memperhatikan empat hal penting yakni:

1. Pidana mati bukan lagi merupakan pidana pokok, melainkan sebagai pidana yang bersifat khusus dan alternatif;

2. Pidana mati dapat dijatuhkan dengan masa percobaan selama sepuluh tahun yang apabila terpidana berkelakuan terpuji dapat diubah dengan pidana penjara seumur hidup atau selama 20 tahun;

3. Pidana mati tidak dapat dijatuhkan terhadap anak-anak yang belum dewasa;

4. Eksekusi pidana mati terhadap perempuan hamil dan seseorang yang sakit jiwa ditangguhkan sampai perempuan hamil tersebut melahirkan dan terpidana yang sakit jiwa tersebut sembuh.

Selain daripada putusan MK pada poin nomor 4, hal itu diperkuat pula dengan pasal 7 Undang-Undang No.2/Pnps/1964 yang pada pasalnya menjelaskan bahwa apabila terpidana sedang hamil, maka boleh dilakukan eksekusi mati terhadapnya 40 hari setelah anaknya dilahirkan. Berkaitan dengan putusan MK dalam poin nomor 4 yang menyebutkan bahwa "Eksekusi pidana mati terhadap perempuan hamil dan seseorang yang sakit jiwa ditangguhkan sampai perempuan hamil tersebut melahirkan dan terpidana yang sakit jiwa tersebut sembuh" disitu terdapat hak-hak narapidana untuk dapat ditangguhkan eksekusi matinya.

Beberapa kasus penundaan eksekusi pidana mati di Indonesia memiliki alasan yang beragam dan memang terdapat beberapa aturan yang diperbolehkan menunda eksekusi pidana mati. Pengertian narapidana sendiri terdapat didalam pasal 1 angka 7 Undang-Undang No.12 Tahun 1995 tentang pemasyarakatan bahwa narapidana ialah yang menjalani pidana hilang kemerdekaan di Lapas.

Kasus yang menarik perhatian adalah kasus terpidana mati asal Pakistan yaitu Zulfiqar Ali yang divonis mati akibat kasus penyelundupan heroin seberat 300 gram pada tahun 2014. Ada beberapa alasan mengapa Zulfiqar tidak patut 
dieksekusi, yang pertama adalah dilihat dalam konteks hukum sebelum eksekusi dilakukan adalah tingkat berbahaya si terpidana mati, dan yang kedua Zulfiqar tidak lagi berbahaya dan tidak akan melakukan kejahatan kembali karena tengah dirawat di rumah sakit akibat kanker hati stadium IV. Hingga pada tahun 2016 Zulfiqar menjadi salah satu terpidana mati yang eksekusinya ditunda dengan alasan yuridis dan non-yuridis. Hingga tahun 2018 sejak saat ditundanya eksekusi Zulfiqar, ia dinyatakan meninggal di rumah sakit Medistra akibat penyakit kanker hati stadium IV yang dideritanya.

Berdasarkan latar belakang diatas, maka rumusan masalah yang akan diangkat adalah pertama mengenai bagaimana pelaksanaan eksekusi mati di Indonesia dan yang kedua apakah seorang terpidana mati yang mengalami sakit kronis mempunyai hak untuk mendapatkan penundaan eksekusi mati. Penelitian ini merupakan penelitian hukum dengan metodologi pendekatan peraturan perundangundangan, pendekatan konsep, dan pendekatan kasus.

\section{Tata Cara Pelaksanaan Pidana Mati di Indonesia}

Tujuan pidana mati adalah untuk menjatuhkan dan menjalankannya selalu diarahkan untuk khalayak ramai, agar dengan ancaman pidana mati tersebut masyarakat akan takut melakukan perbuatan-perbuatan yang kejam dan akan mengakibatkan mereka dihukum mati. ${ }^{6}$ Pidana mati masih diperlukan sebagai alat pencegahan (prevention) bagi orang-orang agar tidak melakukan kejahatankejahatan berat. Kemudian pandangan yang sama juga dikemukakan oleh seorang ahli hukum Belanda, van Hattum, menurutnya, pidana mati merupakan sebuah pidana yang mutlak diperlukan sebagai tindakan dalam keadaan khusus pada taraf kemajuan zaman sekarang. ${ }^{7}$

Menurut Sudarto, pidana adalah penderitaan yang sengaja dibebankan kepada orang yang sedang melakukan perbuatan yang memenuhi syarat-syarat

\footnotetext{
6 Wirjono Prodjodikoro, Asas-Asas Hukum Pidana Di Indonesia (Refika Aditama 2011).[175.]

7 ibid.
} 
tertentu. ${ }^{8}$ Roeslan Saleh pun berpendapat bahwa pidana merupakan reaksi atas delik yang mewujudkan suatu nestapa dan dengan sengaja ditimpahkan negara kepada pembuat delik tersebut. ${ }^{9}$ Sir Robert Cross dalam bukunya yang berjudul The English Sentencing System berpendapat bahwa "punishment is the inflication of pain by the state on someone who has been convicted of an offence". ${ }^{10}$

Berdasarkan tujuannya, teori pemidanaan dibedakan menjadi tiga kelompok yaitu teori absolut (pembalasan), teori relatif (teori tujuan), dan teori gabungan. ${ }^{11}$ Teori absolut yang juga dikenal dengan teori proporsionalitas. ${ }^{12}$ Maka pemberian pidana disini ditujukan sebagai bentuk pembalasan terhadap orang yang telah melakukan kejahatan. Tujuan dari segi pemidanaan sebagai pembalasan pada umumnya dapat menimbulkan rasa puas bagi orang yang melakukan tindak pidana agar mendapat imbalan yang setimpal. Penderitaan yang diakibatkan oleh pidana harus memiliki batas, disamping itu beratnya pidana tidak boleh melebihi kesalahan terdakwa, bahkan tidak dengan alasan-alasan preventif sekalipun. ${ }^{13}$

Teori yang selanjutnya adalah teori relatif atau teori tujuan, teori ini memandang pemidanaan bukan sebagai pembalasan atas kesalahan si pelaku, tetapi sebagai sarana mencapai tujuan bermanfaat untuk melindungi masyarakat menuju kesejahteraan (de handhaving der maatshappeljikeord.) ${ }^{14}$ Menurut tokoh Leonard, teori pemidanaan ini bertujuan untuk mencegah dan mengurangi sebuah kejahatan.

Teori yang terakhir adalah teori gabungan, teori ini adalah kombinasi dari teori relatif. Teori gabungan memiliki tujua untuk selalu membalas kesalahan penjahat dan sekaligus untuk melindungi masyarakat melalui ketertiban dengan

\footnotetext{
8 Soedarto, Hukum Pidana 1 (Yayasan Soedarto 1990).[9].

9 Roeslan Saleh, Stelsel Pidana Indonesia (Aksara Baru 1978).[5].

10 Sir Rupert Cross dan Andrew Ashworth, 1981, The English Sentencing System, (Butterworths 1981).[124].

${ }^{11}$ Yon Artiono Arba'I, Aku Menolak Pidana mati (Kepustakaan Populer Gramedia 2015).[99].

12 Sholehuddin, Sistem Sanksi dalam Hukum Pidana, Ide Dasar Double Track System\&Implementasinya (PT. Raja Grafindo Persada 2003).[34].

13 Muladi dan Barda Nawawi Arief, Pidana dan Pemidanaan (Badan Penyediaan Bahan Kuliah FH UNDIP 1994).[13].

14 ibid.
} 
ketentuan beratnya pidana tidak boleh melampaui batas pembalasan yang adil. ${ }^{15}$ Jika berdasarkan beberapa teori pemidanaan, maka penerapan pidana mati di Indonesia sudah tepat diterapkan pada kejahatan tertentu misalnya extraordinary crime seperti kejahatan narkotika, terorisme dan pelanggaran HAM berat.

Pidana mati diterapkan di Indonesia dimulai sejak adanya KUHP. Undangundang ini dibawa oleh Belanda pada zaman kolonial pada tahun 1981 dan masih dipertahankan hingga sekarang. Berdasarkan sejarah eksekusi pidana mati telah dikenal sejak zaman kerajaan. ${ }^{16}$ Apabila dilihat dalam urutan sanksi pidana dalam KUHP, pidana mati merupakan pidana puncak hal itu dapat dilihat karena pidana mati berada dalam urutan paling atas. Pelaksanaan pidana mati baru dapat dilaksanakan apabila seseorang telah melakukan upaya hukum.

Beberapa pakar pidana berpendapat tetap dipertahankannya pidana mati adalah karena pidana mati dianggap mampu dan efektif dalam memberantas kejahatan. Pidana mati dipertahankan secara normatif maupun praktis. Secara normatif terbukti adanya beberapa Undang-undang yang mencantumkan pidana mati, sedangkan secara praktis terlihat dalam putusan hakim dalam sidang yang berulang kali menjatuhkan pidana mati terutama dalam perkara narkotika, psikotropika dan terorisme. Semakin banyak delik yang diancam pidana mati di Indonesia. ${ }^{17}$

Praktik pidana mati pada masa kolonial belanda dalam pasal 11 KUHP dilakukan dengan cara digantung sesuai dengan isi pasal $11 \mathrm{KUHP}$ ialah: "pidana mati dijalankan oleh algojo pada tempat gantungan dengan menjerat tali yang terikat di tiang gantungan pada leher terpidana kemudian menjatuhkan papan tempat terpidana berdiri." Setelah masa kemerdekaan pelaksanaan pidana mati dilakukan dengan cara ditembak mati, hal ini diatur dalam Penetapan Presiden No.2 Tahun tentang Tata Cara Pelaksanaan Pidana Mati yang Dijatuhkan oleh Pengadilan di

\footnotetext{
${ }^{15}$ Samosir Djisman, Fungsi Pidana Penjara Dalam Sistem Pemidanaan di Indonesia. (Bina Cipta 1992).[13].

16 Robby Setiawan Permana Putra, R.B. Sularto dan Untung Sri Hardjanto, 'Problem Konstitusional Eksistensi Pelaksanaan Pidana Mati di Indonesia' (2016) 5 Diponegoro Law Jurnal.[2]

17 Farid, A.Z. Abidin dan Andi Hamzah, Bentuk-Bentuk Khusus Perwujudan Delik, (Percobaan, Penyertaan, dan Gabungan Delik) dan Hukum Penintesier (Sumber Ilmu Jaya 2002). [326].
} 
Lingkungan Peradilan Umum dan Militer yang ditetapkan menjadi Undang-Undang Nomor 5 Tahun 1969 (yang selanjutnya disebut dengan UU No.2/Pnps/1964). ${ }^{18}$

Dari sisi pelaksanaannya Pasal 11 KUHP sudah tidak relevan lagi seiring dengan perkembangan kemajuan revolusi di Indonesia. ${ }^{19}$ Didalam UU No.2/ Pnps/1964 tidak terdapat definisi norma terkait pidana mati, namun tetap dikeluarkan karena beberapa pertimbangan dengan tidak mengurangi ketentuan dari hukum acara pidana yang ada. Tata cara pelaksanaan pidana mati lebih lanjut diatur dalam Peraturan Kapolri No.12 Tahun 2010 tentang Tata Cara Pelaksanaan Pidana Mati (yang selanjutnya disebut Perkap Polri 12/2010).

Pada tahun 2008 UU No.2/Pnps/1964 pernah dilakukan uji formil dan materiil. Pengujian tersebut dilakukan oleh terpidana mati Amrozi, Ali Ghufron, dan Abdul Azis dalam perkara permohonan pengujian UU No. 2/Pnps/1964yang telah ditetapkan menjadi undang-undang oleh UU No. 5 Tahun 1969 terhadap UUD NRI 1945 dengan nomor putusan 21/PUU-VI/2008. Terhadap pengujian formil (formele toetsingrecht) pemohon mempermasalahkan adanya undang-undang a quo kontradiksi dengan ketentuan pasal 11 KUHP. Hubungan pasal 11 KUHP dengan UU No No. 2/Pnps/1964 (in casu Pasal 1 dan Pasal 14 ayat (4)). ${ }^{20}$

Sedangkan Pengujian materiil (materiele toetsingrecht) tentang frase “dilakukan dengan ditembak mati”(Pasal1) dan Pasal 14 ayat(4)UUNo. 2/Pnps/1964 dianggap bertentangan dengan Pasal 28I ayat (1) UUD NRI 1945. Pemohon tidak memberikan penjelasan mengenai pelaksanaan hukuman mati seperti apa yang dapat membebaskan terpidan mati dari rasa sakit sehingga terhindar dari adanya kesan penyiksaaan sebagaimana dimaksud dalam ketentuan Pasal 28I UUD NRI 1945. Selain itu pemohon lebih memilih pelaksanaan eksekusi pidana mati dengan cara menggantung terpidana mati di tiang sesuai dengan ketentuan Pasal 11 KUHP daripada dengan cara ditembak mati sesuai dengan ketentuan UU No.2/Pnps/1964,

\footnotetext{
${ }^{18}$ R. Sughandii, KUHP Dan Penjelasannya, (Usaha Nasional 1980).[14].

19 I Wayan Wardana, 'Kebijakan Formulasi Pidana Mati dalam Tindak Pidana Narkotika di Indonesia’ (2014) 5.[ 275].

${ }^{20}$ Putusan Mahkamah Konstitusi Nomor 21/PUU-VI/2008.
} 
tetapi pemohon tidak menjelaskan secara rinci apakah pelaksanaan eksekusi pidana mati dengan cara digantung di tiang tidak menyakitkan dan terbebas dari rasa sakit. Menurut Pemerintah, pengertian rasa sakit bagi terpidana mati yang sedang menjalani eksekusi pidana mati tidak termasuk penyiksaan karena pada hakikatnya pelaksanaan eksekusi pidana mati tidak dimaksudkan untuk menimbulkan adanya rasa sakit, namun sebagai konsekuensi logis dari proses hukuman atas putusan pengadilan yang memiliki kekuatan hukum tetap (inkracht van gewijsde). Dari berbagai konluksi mengenai pengujian formil dan materiil tersebut, dalam amar putusannya Hakim Konstitusi menyatakan bahwa permohonan Pemohon baik mengenai pengujian formil dan materiil ditolak untuk seluruhnya.

Teknis pelaksanaan pidana mati yang diatur Perkap Polri 12/2010 diatur didalam ketentuan umum yaitu Pasal 1 angka 3 mengenai definisi mengenai pidana mati/pidana mati yaitu salah satu hukuman pokok yang dijatuhkan oleh hakim kepada terpidana yang telah memperoleh kekuatan hukum tetap. ${ }^{21}$ Terdapat 4 tahapan:

1. Tahap persiapan;

2. Tahap pengorganisasian;

3. Tahap pelaksanaan; dan

4. Tahap pengakhiran.

Perka polri 12/2010 memang lebih memperinci pelaksaan teknis pidana mati, karena itulah agar lebih jelas maka dibagilah menjadi 4 tahapan. Proses pelaksanaan pidana mati dalam Pasal 15 Perka Polri 12/2010. Pelaksanaan pidana mati dijalankan setelah lewat 30 hari terhitung mulai hari setelah keputusan tidak dapat diubah lagi dan Keputusan Presiden tentang penolakan Grasinya diterima oleh Kepala Kejaksaan Negeri dan apabila terpidana hamil, maka pidana mati dijalankan setelah 40 hari dari kelahiran anaknya. ${ }^{22}$ Pidana mati ini merupakan pidana yang bersifat khusus karena pengkhusuan ini bersifat total dan menyeluruh. ${ }^{23}$ Pidana mati dinyatakan sebagai pidana pokok yang bersifat mengancam dan khusus serta harus selalu diancamkan secara alternatif. Dari

\footnotetext{
${ }^{21}$ Peraturan Kepala Kepolisian Negara Republik Indonesia Nomor 12 Tahun 2010 Tentang Tata Cara Pelaksanaan Pidana Mati, Ps. 1 angka 3

22 Surat Keputusan Jaksa Agung, No. B-235/E/3/1994.

23 Taufik Makarao, Pembaharuan Hukum Pidana Indonesia (Kreasi Wacana 2005).[213].
} 
beberapa penjelasan diatas mengenai tata cara pidana mati yang diatur dalam Perka Polri 12/2010 hanya benar-benar membahas mengenai teknis lebih lanjut dari UU No.2/Pnps/1964 agar hukum lebih bisa ditegakkan. Penegakan hukum ini dilakukan agar norma-norma dapat berfungsi nyata sebagai pedoman dalam hubungan hukum di kehidupan bermasayarakat dan bernegara. ${ }^{24}$

\section{Pemenuhan Hak Terpidana Mati yang Mengalami Sakit Kronis}

Berkaitan dengan narapidana yang akan dieksekusi mati, Negara wajib memenuhi hak-hak narapidana sebelum maupun sesudah dilaksanakannya eksekusi. Narapidana juga sebagai seorang manusia yang merupakan bagian dari masyarakat umum. ${ }^{25}$ Pengertian narapidana sendiri didalam Pasal 7 angka 1 UU No.25 Tahun 1995 tentang Pemasyarakatan ialah terpidana yang menjalani pidana hilang di Lembaga Pemasyarakatan (LAPAS). Hak narapidana juga telah diatur didalam UU Pemasyarakatan. LAPAS sendiri sebenarnya berfungsi untuk meniadakan atau mengurangi hak-hak narapidana ${ }^{26}$ namun disatu sisi Negara tetap harus menghormati HAM karena PBB sendiri telah mengakui bahwa Negara harus menghormati HAM setiap warga negaranya tidak terkecuali tahanan atau narapidana.

Hak narapidana yang telah diatur dalam pasal 14 ayat (1) UU Pemasyarakatan antara lain:

a. menjalankan ibadah sesuai dengan agama dan kepercayaannya;

b. mendapatkan perawatan baik secara rohani maupun jasmani;

c. mendapatkan pendidikan dan pengajaran;

d. mendapatkan pelayanan kesehatan dan makanan yang layak;

e. menyampaikan keluhan;

f. mendapatkan bahan bacaan dan mengikuti siaran media massa lainnya yang tidak dilarang;

g. mendapatkan upah premi atau gaji atas pekerjaan yang dilakukan;

h. menerima kunjungan keluarga, penasihat hukum, atau orang tertentu lainnya;

\footnotetext{
${ }^{24}$ Nelvita Purba dan Sri Sulistyawati, Pelaksanaan Hukuman Mati: Perspektif Hak Asasi Manusia dan Hukum Pidana di Indonesia (Graha Ilmu).[155].

25 Jumalia, Peran Pemerintah Dalam Pemenuhan Hak Narapidana Untuk Memperoleh Pelayanan Kesehatan Yang Layak, Tesis, (Program Pascasarjana Universitas Tanjungpura, 2017).[17].

26 Citra Anggraeni Puspitasari, Pelanggaran Hak Tahanan Narapidana Pada Rumah Tahanan Negara Serta Lembaga Pemasyarakatan Dalam Kajian Hukum Administrasi, TESIS, (Fakultas Hukum Universitas Airlangga 2018).[30].
} 
i. mendapatkan pengurangan masa pidana (remisi);

j. mendapatkan kesempatan berasimilasi termasuk cuti untuk mengunjungi keluarga;

k. mendapatkan pembebasan bersyarat;

I. mendapatkan cuti menjelang bebas; dan

m. mendapatkan hak lain sesuai dengan peraturan perundang-undangan yang berlaku.

Ketentuan lebih lanjut mengenai syarat dan tata cara pelaksanaan hak narapidana pada Pasal 14 ayat (1) UU Pemasyarakatan diatur dalam PP Nomor 32 Tahun 1999 tentang Syarat dan Tata cara Pelaksanaan Hak Warga Binaan Pemasyarakatan. Didalam PP 32/1999 menjabarkan lebih luas lagi mengenai pasal yang terdapat dalam UU Pemasyarakatan, misalkan didalam pasal 14 ayat (2) huruf d UU Pemasyarakatan narapidana berhak mendapatkan pelayanan kesehatan dan makanan yang layak, dalam PP No. 32/1999 bagian keempat dalam beberapa pasalnya menjabarkan lebih rinci mengenai pelayanan kesehatan dan makanan yang dimaksud. Pelayanan kesehatan yang dimaksud dalam pasal 1 angka 4 PP No. 32/1999 berbunyi : "pelayanan kesehatan adalah upaya promotif, preventif, kuratif dan rehabilitatif di bidang kesehatan bagi narapidana dan anak didik pemasyarakatan di LAPAS".

Narapidana juga memiliki hak atas kesehatan sesuai dengan ketentuan pasal 25 ayat (1) DUHAM. Pelayanan kesehatan sendiri terdapat di dalam Pasal 1 angka 2 Undang-undang No. 36 Tahun 2009 tentang kesehatan bahwa sumber daya di bidanng kesehatan bisa berupa dana, tenaga, perbekalan kesehatan, ketersediaan farmasi dan alat kesehatan serta pelayanan kesehatan yang dilakukan oleh Pemerintah, Pemerintah Daerah, dan masyarakat guna pemenuhan upaya kesehatan.

Didalam lembaga pemasyarakatan (LAPAS), seorang narapidana bisa saja terkena penyakit selama menjalani masa pidana, penyakit tersebut bisa disebabkan karena beberapa faktor. Berdasarkan penelitian Vorenberg 1990, jika dilihat dari lingkungan fisik penjara di Indonesia, dari segi akomodasi, makanan, kebersihan diri serta pelayanan kesehatan masih berada dibawah standar, kondisi ini sangat rentan menyebabkan penyakit. Selain itu kondisi stress dapat menyebabkan 
perubahan di lingkungan baik fisik maupun mental yang dirasa dapat menganggu dan mengakibatkan dirinya terancam. ${ }^{27}$

Penyakit kronis merupakan jenis penyakit degeneratif yang berkembang atau bertahan dalam jangka waktu yang sangat lama, yakni lebih dari enam bulan. Orang yang menderita penyakit kronis cenderung memiliki tingkat kecemasan yang tinggi dan cenderung mengembangkan perasaan hopelessness dan helplessness karena berbagai macam pengobatan tidak dapat membantunya sembuh dari penyakit kronis (Sarafino, 2006). ${ }^{28}$ Sedangkan menurut KBBI sendiri pengertian kronis artinya adalah berlangsung dalam waktu lama atau terus menerus. Secara medis dapat diartikan adalah kondisi (penyakit) yang berlangsung dalam waktu lama dan secara terus menerus. ${ }^{29}$ Upaya memenuhi hak narapidana masih banyak yang hanya sebatas pengakuan saja dalam perundang-undangan namun implementasinya masih jauh dari realita. ${ }^{30}$ Pemerintah juga memiliki peran yang sangat penting dalam melakukan pemenuhan pelayanan kesehatan bagi narapidana, hal ini terkait dengan fungsi pemerintah sebagai alat untuk meningkatkan kesehatan masyarakat tidak terkecuali narapidana. Bahwa selain diatur dalam UU Kesehatan, Peraturan Pemerintah Nomor. 32 tahun 1999 tentang Hak Pelayanan Kesehatan Pada Warga Binaan (yang selanjutnya disebut PP No. 32/1999) juga mengatur beberapa hak pelayanan kesehatan bagi warga binaan.

Hak kesehatan terhadap narapidana ini memiliki korelasi terhadap pelaksanaan pidana mati di Indonesia, hal ini berkaitan dengan adanya penundaan pelaksanaan pidana mati di Indonesia. Beberapa hal yang dapat menunda pidana mati antara lain ketika seorang narapidana mengajukan upaya hukum seperti banding, kasasi dan peninjauan kembali atau saat narapidana sedang mengajukan grasi ke Presiden. Dikarenakan pidana mati merupakan pidana pokok yang bersifat khusus dan selalu dirumuskan secara alternatif, maka putusan yang telah in krach dapat

\footnotetext{
${ }^{27}$ Pandji Anoraga, Psikologi Kerja, (PT Rineka Cipta 2001).[34].

28 Sarafino, E. P, Health Psychology : Biopsychosocial Interactions. Fifth Edition.(USA: John Wiley \& Sons, 2006).[275].

${ }^{29} \mathrm{KBBI},<$ https://kbbi.kemdikbud.go.id/entri/kronis $>$, diakases pada tanggal 22 February 2019.

30 Jumalia,Op.Cit.[7].
} 
dilakukan perubahan sesuai dengan tujuan pemidanaan. ${ }^{31}$ Selain itu dalam pasal 7 UU No.2/Pnps/1964 apabila terpidana hamil maka pelaksanaan pidana mati baru dapat dilaksanakan 40 hari setelah anaknya dilahirkan, hal ini juga berlaku bagi narapidana yang mengalami gangguan jiwa saaat sudah berada di LAPAS.

Penundaan eksekusi mati menjadi persoalan yang muncul di masyarakat. Permasalahan ini menyebabkan semakin kompleksnya problematika pidana mati. Didalam pelaksanaan eksekusi pidana mati dimungkinkan terdapat penundaan yang mengakibatkan terpidana mati mengalami ketidakpastian hukum. Penundaan tersebut dapat disebabkan oleh faktor yuridis dan non yuridis. Tekanan internasional pun dapat menjadi faktor ditundanya eksekusi pidana mati. Terpidana mati bisa saja mengalami death row phenomenon. Terpidana mati yang mengalami proses panjang berpotensi besar mendapatkan tingkat stress yang tinggi, depresi dan gangguan kejiwaan. ${ }^{32}$

Penundaan pelaksanaan pidana mati tersebut menyebabkan terpidana mati mengalami penderitaan lebih dari satu sanksi pidana. Hal ini bertentangan dengan sistem pemidanaan di Indonesia. Untuk menghindari pelanggaran terhadap terpidana mati, eksekusi terhadap terpidana mati yang telah inkracht harus segera dilaksanakan dan segera dibuat peraturan perundang-undangan yang pasti tentang penundaan pelaksanaan pidana mati sebagaimana diatur dalam RKUHP Pasal 89 ayat 1 , yang menyebutkan bahwa penundaan pelaksanaan pidana mati dengan masa percobaan selama 10 tahun apabila:

1. Reaksi masyarakat terhadap terpidana tidak terlalu besar;

2. Terpidana menunjukkan rasa menyesal dan ada harapan untuk diperbaiki;

3. Kedudukan terpidana dalam penyertaan tindak pidana tidak terlalu penting; dan 4. Ada alasan yang meringankan.

Didalam pelaksanaan eksekusi pidana mati dimungkinkan terdapat penundaan yang mengakibatkan terpidana mati mengalami ketidakpastian hukum. Penundaan

\footnotetext{
${ }^{31}$ Soerjono Soekanto, Faktor-faktor Yang Mempengaruhi Penegakan Hukum (Rineka Cipta 1986).[8].

32 ICJR, 'Calon Tereksekusi Mati Telah Alami Trauma akibat Penundaan Eksekusi yang Berkepanjangan (death row phenomenon)',(ICJR, 2015) $<$ http://icjr.or.id/icjr, $>$ diakses pada tanggal 30 January' 2019
} 
tersebut dapat disebabkan oleh faktor yuridis dan non yuridis. Tekanan internasional pun dapat menjadi faktor ditundanya eksekusi pidana mati.

Sebagai contoh kasus yang telah dijelaskan dalam bab pendahuluan, seorang narapidana yakni Zulfiqar Ali yang terlibat kasus penyelundupan heroin seberat 300 gram pada tahun 2004 dan telah mendapatkan putusan berupa pidana mati yang akan dilaksanakan pada tahun 2016. Zulfiqar divonis oleh dokter menderita kanker hati stadium IV dan sering sekali mendapatkan perawatan intensif selama didalam LAPAS. Pelaksaan eksekusi mati terhadap Zulfiqar ditunda oleh Jaksa Agung dikarenakan faktor yuridis dan non-yuridis. Peneliti ICJR berpendapat berpendapat bahwa pada kasus Zulfiqar ini memang normatifnya tidak mengatur mengenai pembatalan eksekusi mati apabila terpidana ini mengalami sakit. Namun, eksekusi tetap tidak boleh dilakukan karena bisa dikatakan ada kekosongan hukum. ${ }^{33}$

Permasalahan selanjutnya dari kasus Zulfiqar Ali ini adalah Presiden telah menjanjikan akan memberikan grasi kepada Zulfiqar ${ }^{34}$ pada bulan Januari dengan alasan kemanusiaan namun grasi tersebut tidak kunjung terbit dikarenakan belum ada pertimbangan dari Mahkamah Agung (MA). Hingga 2 (dua) tahun sejak ditundanya eksekusi gelombang III ini, Zulfiqar dinyatakan masuk rumah sakit kembali karena kondisinya semakin memburuk, dan sampai pada 31 Mei 2018 Zulfiqar Ali dinyatakan meninggal dunia akibat kanker hati stadium IV yang dideritanya dan hingga ia dinyatakan meninggal dunia. Sampai ia meninggal dunia pun, grasi yang telah diajukan dan melewati batas waktu tidak kunjung diterbitkan. Padahal didalam Pasal 10 UU No. 5/2010 tentang perubahan atas UU No. 22/2002 tentang Grasi bahwa dalam jangka waktu paling lambat 30 (tigapuluh) hari terhitung sejak diterima salinan berkas perkara, Mahkamah Agung harus mengirimkan pertimbangan tertulis tersebut kepada presiden. ${ }^{35}$

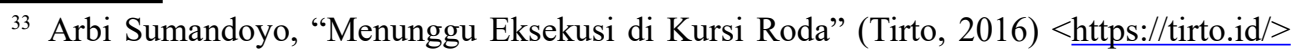
diakses pada tanggal 13 Maret 2019

${ }^{34}$ Al Araf, "Mahkamah Agung Lalai Memberikan Petimbangan Grasi Zulfiqa Ali kepada Presiden",(Tribunnews, 2018)< http://www.tribunnews.com>, diakses pada tanggal 18 Maret 2019..

35 Setyo Aji Harjanto, "Imparsial Ungkit Janji Jokowi Grasi Untuk Terpidana Zulfiqar, (Cnn

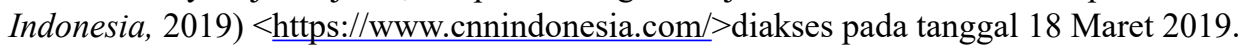


Berdasarkan surat Kejaksaan Agung Republik Indonesia Nomor: B-128/E/3/1995 perihal Kejaksaan sebagai eksekutor putusan pengadilan yang telah memperoleh kekuatan hukum tetap dapat melaksanakan penundaan pelaksanaan Eksekusi pengadilan apabila ada alasan seperti yang tercermin didalam penjelasan pasal 27 ayat (1) b jo. Pasal 8 ayat (4) UU Nomor 5 Tahun 1991 tentang Kejaksaan adalah:

a. Alasan yuridis terpidana memohon penundaan;

b. Pelaksanaan hukuman sehubungan dengan permohonan grasinya dan dalam hal hukuman mati (Pasal 2, Pasal 3 Undang-undang No. 3 Tahun 1950 tentang Permohonan Grasi);

c. Alasan perikemanusiaan seperti terpidana dalam keadaan hamil tua, sakit keras dan sebagainya.

Jadi pada dasarnya eksekusi mati tidak dapat ditunda ataupun dibatalkan apabila terpidana mati sedang mengalami sakit kronis, karena tidak ada ketentuan didalam Undang-undang yang mengatur untuk menunda atau membatalkan eksekusi apabila terpidana telah divonis mengalami sakit kronis dan tidak dapat disembuhkan. Eksekusi tersebut dapat dilakukan kapan pun dan dilaksanakan dengan produk hukum berupa Surat Perintah Pelaksanaan Eksekusi Pidana Mati. ${ }^{36}$

\section{Kesimpulan}

Pengaturan tentang pelaksanaan eksekusi pidana mati dalam pasal 11 KUHP yang semula hukuman gantung tidak lagi diberlakukan dikarenakan terdapat UU No.2/Pnps/1964 tentang Tata Cara Pelaksanaan Pidana Mati yang Dijatuhkan oleh Pengadilan di Lingkungan Peradilan Umum dan Militer, menjadi hukuman tembak mati yang didasarkan pada asas lex posteriori derogate legi priori, hukuman gantung tidak dipergunakan untuk hukuman mati dikarenakan tidak sesuai lagi dengan perkembangan dan keadaan bangsa Indonesia dan hukuman tembak mati dirasa lebih sedikit menimbulkan derita ataupun siksaan.

\footnotetext{
${ }^{36}$ Suriyanto, "Surat Perintah Eksekusi Terpidana Mati dikeluarkan" (CNN Indonesia 2015

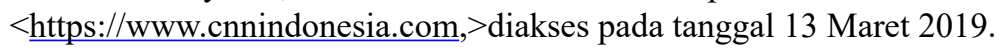


Terpidana mati yang mengalami sakit kronis didalam LAPAS dan hingga waktu yang telah diputuskan akan dieksekusi mati, tidak dapat ditangguhkan atau ditunda dikarenakan undang-undang tidak mengatur mengenai penundaan eksekusi mati terhadap terpidana mati yang mengalami sakit kronis. Undang-undang hanya mengatur mengenai eksekusi mati terhadap terpidana mati yang sedang hamil untuk menyelamatkan anak didalam kandungannya, dan apabila terpidana sedang mengajukan upaya hukum dan Grasi, namun dalam surat keputusan Jaksa Agung no. B-128/E/3/1995 menjelaskan bahwa bisa saja eksekusi pidana mati ditunda dengan alasan kemanusiaan apabila terpidana dalam keadaan hamil tua dan sakit keras namun hal itu harus dikaji kembali secara komprehensif.

\section{Daftar bacaan}

\section{Buku}

Akhiar Salmi, Eksistensi Hukuman Mati, (Aksara persada 1985).

Farid, A.Z. Abidin dan Andi Hamzah, Bentuk-Bentuk Khusus Perwujudan Delik, (Percobaan, Penyertaan, dan Gabungan Delik) dan Hukum Penintesier, (Sumber Ilmu Jaya 2002).

Nelvita Purba dan Sri Sulistyawati, Pelaksanaan Hukuman Mati: Perspektif Hak Asasi Manusia dan Hukum Pidana di Indonesia, (Graha Ilmu).

Pandji Anoraga, Psikologi Kerja, (PT Rineka Cipta 2001).

R. Sughandii, KUHP Dan Penjelasannya, (Usaha Nasional, Surabaya 1980).

Roeslan Saleh, Stelsel Pidana Indonesia, (Aksara Baru 1978).

Samosir Djisman, Fungsi Pidana Penjara Dalam Sistem Pemidanaan di Indonesia. (Bina Cipta 1992).

Sarafino, E. P, Health Psychology : Biopsychosocial Interactions. Fifth Edition. USA: John Wiley \& Sons, 2006).

Soedarto, Hukum Pidana 1, (Yayasan Soedarto 1990).

Wirjono Prodjodikoro, Asas-Asas Hukum Pidana Di Indonesia, (Eresco 1989). 
Soerjono Soekanto, Faktor-faktor Yang Mempengaruhi Penegakan Hukum, (Rineka Cipta, 1986).

Sholehuddin, Sistem Sanksi dalam Hukum Pidana, Ide Dasar Double Track System\&Implementasinya, (PT. Raja Grafindo Persada 2003).

Sir Rupert Cross dan Andrew Ashworth, 1981, The English Sentencing System, (Butterworths 1981).

Taufik Makarao, Pembaharuan Hukum Pidana Indonesia, (Kreasi Wacana 2005).

Yon Artiono Arba'I, Aku Menolak Pidana mati, (Kepustakaan Populer Gramedia 2015).

\section{Laman}

Al Araf, "Mahkamah Agung Lalai Memberikan Petimbangan Grasi Zulfiqa Ali kepada Presiden",(Tribunnews, 2018)<http://www.tribunnews.com>, diakses pada tanggal 18 Maret 2019.

Arbi Sumandoyo, "Menunggu Eksekusi di Kursi Roda" (Tirto, 2016) <https://tirto. id/> diakses pada tanggal 13 Maret 2019.

ICJR, 'Calon Tereksekusi Mati Telah Alami Trauma akibat Penundaan Eksekusi yang Berkepanjangan (death row phenomenon)',(ICJR, 2015) < http://icjr. or.id/icjr,> diakses pada tanggal 3 Januari 2019.

KBBI, <https://kbbi.kemdikbud.go.id/entri/kronis>, diakases 22 February 2019.

Setyo Aji Harjanto, “Imparsial Ungkit Janji Jokowi Grasi Untuk Terpidana Zulfiqar, (Cnn Indonesia, 2019) <https://www.cnnindonesia.com/>diakses pada tanggal 18 Maret 2019.

Suriyanto, "Surat Perintah Eksekusi Terpidana Mati dikeluarkan", (CNN Indonesia, $2015<$ https://www.cnnindonesia.com,>dikunjungi pada tanggal 13 Maret 2019.

\section{Perundang-undangan}

Undang-undang Dasar Negara Republik Indonesia Tahun 1945.

Undang-undang Republik Indonesia Nomor 73 Tahun 1958 Tentang Menyatakan Berlakunya Undang-undang Nomor 1 Tahun 1946 Republik Indonesia Tentang Peraturan Hukum Pidana Untuk Seluruh Wilayah Republik Indonesia dan Mengubah Kitab Undang-undang Hukum Pidana (Lembar Negara Republik 
Indonesia Tahun 1958 Nomor 127, Tambahan Lembar Negara Republik Indonesia Nomor 1660).

Undang-Undang Nomor 39 Tahun 1999 tentang Hak Asasi Manusia (Lembaran Negara Republik Indonesia Tahun 1999 Nomor 165, Tambahan Lembaran Negara Republik Indonesia Nomor 3886)

Undang-Undang Republik Indonesia Nomor 36 Tahun 2009 tentang Kesehatan (Lembaran Negara Republik Indonesia Tahun 2009 Nomor 144, Lembaran Negara Republik Indonesia Nomor 5063)

Undang-Undang No. 12 Tahun 1995 tentang Pemasyarakatan (Lembaran Negara Republik Indonesia Tahun 1997 Nomor 3 Tambahan Lembaran Negara Republik Indonesia Nomor 3614);

Undang-Undang Nomor 2/Pnps/1964 tentang Tata Cara Pelaksanaan Pidana Mati yang Dijatuhkan oleh Pengadilan di Lingkungan Peradilan Umum dan Militer jo. Undang-Undang Nomor 5 Tahun 1969 tentang Pernyataan Berbagai Penetapan Presiden dan Peraturan Presiden Sebagai Undang-Undang (Lembaran Negara Republik Indonesia Nomor 51 Tahun 1969);

Undang-Undang Nomor 22 Tahun 2002 tentang Grasi (Lembaran Negara Republik Indonesia Tahun 2002 Nomor 108, Tambahan Lembaran Negara Republik Indonesia Nomor 4234)

Undang-undang Nomor 12 Tahun 2005 tentang Pengesahan International Covenant On Civil and Political Rights (Lembaran Negara Republik Indonesia Tahun 2005 Nomor 119, Tambahan Lembaran Negara Republik Indonesia Nomor 4558)

Undang-Undang Nomor 35 Tahun 2009 tentang Narkotika (Lembaran Negara Republik Indonesia Tahun 2009 Nomor 143, Tambahan Lembaran Negara Republik Indonesia Nomor 5062)

Undang-Undang Nomor 5 Tahun 2010 tentang Perubahan Atas Undang-Undang Nomor 22 Tahun 2002 tentang Grasi (Lembaran Negara Republik Indonesia Tahun 2010 Nomor 100, Tambahan Lembaran Negara Republik Indonesia Nomor 5150)

Undang-Undang Nomor 48 Tahun 2009 tentang Kekuasaan Kehakiman (Lembaran Negara Republik Indonesia Tahun 2009 Nomor 157, Tambahan Lembaran Negara Republik Indonesia Nomor 5076)

Peraturan Pemerintah Republik Indonesia Nomor 32 Tahun 1999 tentang Tata Cara Pelaksanaan Hak Warga Binaan Pemasyarakatan (Lembaran Negara Republik 
Indonesia Tahun 1999 Nomor 69, Tambahan Lembaran Negara Republik Indonesia Nomor 3846)

Peraturan Kepala Kepolisian Negara Republik Indonesia Nomor 12 Tahun 2010 tentang Tata Cara Pelaksanaan Pidana Mati (Berita Negara Republik Indonesia Tahun 2010 Nomor 242)

HOW TO CITE: Rizka Fatrian Larasanti, 'Eksekusi Pidana Mati Pidana Mati Terhadap Narapidana yang Mengalami Sakit Kronis' (2019) Vol. 2 No. 5 Jurist-Diction. 